\title{
Representations of Death in a Changing World: An Anthropological Perusal of Death Rites of Gurungs in Nepal
}

\author{
Prakash Upadhyay
}

\begin{abstract}
People have developed ceremonies and rituals to help make sense or celebrate an alteration in position, circumstance or relationship. However, over time some have become diluted or rejected for whom they are intended. In majority of cultures, the greatest effort is given to the death rite of passage- and yet paradoxically it is the one that is now most often distorted or lost. This study attempted to describe the multiple aspects of changes that are occurring in Gurung death rite. Gurungs are followers of 'Bonism' but they are under the profound influence of Tibetan Mahayani Lamaism. Gurung community is changing from Mechanical to Organic Solidarity in which the Mechanical Unity of their traditional culture is transforming to loosely united Organic Solidarity of body. Gurung death rites have been influenced by many rudiments-migration, urbanization and modernization due to which there has been the emergence of deformed usages and behaviors in death rite. Urbanization impact on death rite is closely linked to modernization and the sociological process of rationalization, a speedy and historic transformation of Gurung social roots whereby predominantly rural Gurung culture is being rapidly modified by urban ostentatious culture. However, there is very vital element of unity, cooperation, sympathy and we feeling among the Gurungs owing to death rite that has tied all Gurungs under a shared and endorsed bond. It has created a reciprocal relationship between the living and dead-- both
\end{abstract}


depending upon each other. Death rituals have been a means of coordination creating solidarity through 'Syaisyai' which is a social institution for uniting the Gurungs. This bond between giver and gift, the act of giving creates a social bond in Gurung community with an obligation to reciprocate on part of the recipient.

Keywords: Assorted, necromancy, spiritual, autonomous, homogenized, compensation, tarnished

\section{Introduction}

In a multi ethnic and multilingual country Nepal, among the different caste and ethnic groups, Gurung is one of major ethnic group. The Gurung of Nepal have been generally considered an ethnic group known for its internal social cohesion and unity as well as for ability to work well together in a variety of chores despite of having differences in the economic and political conditions between persons (Messerschmidt, 1976). They have a glorious military career in Nepal, Indian and British armies and hence possess a unique Lahure Culture (Culture of going abroad for a career in foreign armies). The total population of Gurung in Nepal are 3,25,622 of which 1.1 Million speak the Gurung language (CBS, 2011).

The Gurungs traditional homeland is in southern hill slopes of the Annapurna Himalayan range of central Nepal mainly in Gandaki region. The historical areas of Gurung are Lamjung and Kaski. They have their own language, cultures, rituals and dresses with Rodi as a major social institution (Pignede, 1966). There is a long history of Gurung which is explained in Gurung traditional religious text called Pye-Tan Lhu-Tan. Gurung follow the customs, traditions and all rituals according to Pye-Tan Lhu-Tan. According to Pye-Tan LhuTan, Gurung (Tamu) refers to the very beginning of civilization, more than eight or nine thousand years ago. It acquaints with different types of rites of passage (rites de passage) which Gurung need to tag along.

Rite of passage is a general theory of socialization articulated to denote rituals marking the transitional phase between childhood and 
full inclusion into a tribe or social group (Van Gennep, 2010). For him, rituals performed at death resemble those played out during other critical periods in the life of the individual, e.g., at birth, social puberty, or marriage. Life is a journey, the individual a passenger. Along the way, the individual confronts periodic challenges which he must manage if he is to move to the next social station. To help the person cope with these crises, society has developed ceremonial responses which Van Gennep (2012) labeled the "rites of passage." Rites of passage investigate and portray various landmarks in an individual's life, for any marked transitional stage, when one's social status is changed. It includes transitions from puberty, marriage and death. Rites of passage in Gurung community are ritual occurrences that symbolize their transition from one status to another. Embedded with rites of passage there are different rituals in Gurung culture. Namrashi Juraunu, Chhaithi, Nwaran, Pashni, Putpute, Ksheur, Bibaha, Antesti kriya and Arghaun etc are the foremost (Gurung, 1977).

All rituals are very important but among these rituals, death rite of passage is extremely vital and compulsory. The death rite of passage of Gurung is divided into three parts: Antesty Kirya, Bayupuja and Arghun (Pae). Gurung mourn for three days to thirteen days according to their culture of the place (region) and their desire. It is called Antesty Kiriya. Bayupuja (Pitripuja or ancestor worship) is done in Mangsir Purnima or Panchami and Baishakh Purnima or Panchami. Some people do Bayupuja after they believe that they suffer because of dead person's soul. The belief is that any family member or livestock will become sick and Gurung priest Ghepren or Pachyu will declare that it is because of dead person's soul (pitry) and people need to do Bayupuja at any suitable time. It is done continuously every Mangsir Purnima (full moon) and Baishakh Purnima until conducting Arghun (Pae) which is a final but crucial after death ritual conducted after a certain period at the comfort of deceased persons family. As the second mortuary rite Pae or Arghun is observed either on the last day of the death pollution or on the $45^{\text {th }}$ day of the dead, and sometimes more than a year depending upon the economic stipulation of the family. On the occasion great offerings are made by the relatives to the deceased. Pae (Arghun) is 
conducted with a religious belief to bestow salvation to dead person's peripatetic soul. Gurungs believe Pae ceremony as salvation of the soul by sending the departed soul to heaven. After their kith and kin discussions, they decide how to manage expenditure for conducting Pae (Arghun), what amount to spend etc. In village areas, kith and kin manage firewood, water etc for Pae. In urban areas, kin households assist by donating money as the offering of small help. Pae (Arghun) is divided into one night (Ek Rate) and three nights (Teen Rate). In three days Pae, on the first day of Pae (Arghun), there occurs the function of hanging clothes, foods etc in a lingo (erected pole) at a tip of bamboo known as Aanla in Gurung lexis. On the second day they perform "Rhiteba" (Ghepren or Lama dance by making effigy of dead person) and Pae (Arghun) ends in the third day with "Kyun chhaba" (grazing sheep) ceremony and descending down Aanla (cloths, foods etc hanged to the tip end of a bamboo). Afterwards the relatives do Syaisyai which is a special tribute of support by offerings money or clothes to the person involved with performing the last rites of deceased. The Syaisyai ceremony is performed to encourage and to give consolation and condolence to the relatives of the deceased. Syaisyai is a benevolent ceremony involved with great money and gift giving tradition.

Gurungs believe that deceased soul reaches heaven after the completion of Pae (Arghun) ceremony. Gurung do not perform Shrada as done by Hindus. However, at the present, under the rapid incursion of migration, modernization, westernization, urbanization and Hinduization, the Lahure culture embedded Gurung community is affected in various fields, in death rite too. Inclination to ostentatious behavior is becoming pervasive. Superfluous expenses has made difficult for the poor people to conduct Pae (Arghun). On the other hand, owing to modernization and urbanization, the new generation is becoming apathetic to their culture; rituals and the importance of rituals are becoming restricted to older generation. The traditional rituals are on the verge of annihilation. Despite this the death ritual embedded with necromancy has become the bond to unite Gurung community which is otherwise fragmenting due to migration, modernization and westernization effects. Death ritual is a contrivance for harmony, interrelations and interaction with 
relatives and it identifies the importance and relation of relatives in Gurung community. Syaisyai by relatives helps economically and socially. But nowadays, the connotation of Syaisyai is becoming similar to exchange only. Currently, Gurung people are doing Syaisyai donating huge money in the anticipation to get good returns and in the course of action poor Gurung people are the nastiest sufferers. It is becoming an immense impediment in Gurung society. Under the strong effect of migration, modernization, urbanization and westernization, the death rite of passage is undergoing through the process of spiky change. From anthropological perspective there is an immense anthropological significance of Gurung death rite of passage because it confirms the social hierarchies, values, beliefs and the altering contexts that are significant in Gurung cultures. Given these, the major objective of this study is to examine the altering death rite of Gurungs and the actors and the factors responsible for the change.

This study is based on 60 Gurung families that migrated from Rupakot V.D.C. (Village Development Committee) of Kaski district to Pokhara sub-metropolitan city. The sampling is based on census with the selection of all 60 households of Rupakot VDC migrated Gurung who are the members of Rupa Samaj in Pokhara. Primary data have been collected by observation, key-informant interview, group interview and household interview. Researcher's observations have yielded more qualitative data. Similarly, key-informants interview has yielded more qualitative data. Secondary data was collected from published and unpublished sources. Secondary data was collected from various literatures, books, documents and websites. The fieldwork for this study was accomplished during February 3-19, 2014.

\section{Profile of Rupakot VDC Migrate Gurung People in Pokhara}

The surge of migration is increasing speedily in Nepal. The Lahure Culture rooted Gurung Society cannot remain unscathed from this trend. Most of Lahure families of Rupakot VDC have migrated to urban areas. Some migrated for getting better facilities, some for education and employment. They settled scattering in different 
parts of Pokhara sub-metropolitan city. The enlisted 60 households in Rupa Samaj (organization) have formed a society named Rupa Samaj in Pokhara. They have joined in a chain for conducting several rituals, customs and functions. One of the objectives of establishing Rupa Samaj was to provide a substitute for the family/ lineage/clan/village network of newly-arrived individuals or nuclear families when performing various rites of passages. It also supplies ritual specialists from its community, logistic support and a physical space needed for major rituals (cremation facilities, Arghun, hall for ceremonies, festivals and so on). This organization has thrived and developed into a huge network made up of complementary structures at local and national levels.

\section{a. Occupation}

The Gurung of Rupakot VDC who migrated to Pokhara has embraced diverse occupations like trade/business, private services, Foreign Service. Majority of respondents are ex-armies and housewives.

\section{Table 1: Occupational Distribution}

\section{Occupation}

Trade/Business

Teacher

Private Service

House wife

Foreign employment

Ex-army

Total

No response

Total

Source: Field Survey, 2014

\section{Frequency}

7

2

4

26

2

18

59

1

60

\section{Percent}

11.7

3.3

6.7

43.3

3.3

30.0

98.3

1.7

100

Among the sixty respondents, the majority (43.3\% respondents) 
were housewives. As many Gurung man are employed in foreign armies, womenfolk are the respondents. Their household chores have been acknowledged as occupation. 30 percent respondents were exarmy. Till at present, in Gurung community there is high prestige for military services. Likewise, 11.7 percent respondents were involved in trade/ business. Similarly, 6.7 percent, 3.3 percent, 3.3 percent respondents were involved respectively in private service, teacher and foreign employment. The agricultural traditions have shifted to modern services sectors after the migration to Pokhara city.

\section{b. Age}

The age of the respondents categorized is, 25 years, 25-35, 35-45, 45-55 and above 55 years. Among total respondents, 11.7 percent respondents were below 25 years who were quite young.

\section{Table: 2: Age Group of Respondents}

$\begin{array}{lll}\text { Age Group } & \text { Frequency } & \text { Percent } \\ \text { Below 25 } & 7 & 11.7 \\ 25-35 & 11 & 18.3 \\ 35-45 & 18 & 30.0 \\ 45-55 & 6 & 10.0 \\ \text { above 55 } & 18 & 30.0 \\ \text { Total } & \mathbf{6 0} & \mathbf{1 0 0 . 0} \\ \text { Source: Field Survey, 2014 } & \end{array}$

18.3 percent respondent's age was $25-35,30$ percent respondents were of the age group 35-45 years, 10 percent respondents were 45-55 years and 30 percent respondents were 55 years above. Generally, above 55 years age groups had more knowledge about Gurung culture including death rite of passage.

\section{c. Religion}

Religion is a belief on spiritual beings. This belief arises from the imagined nature of these beings and is roofed in its validity for every individual (Tylor, 1865). Durkheim (1893) defines religion as 
a unified system of beliefs and practices relative to sacred things, that is to say things that set apart forbidden beliefs and practices and which unite all those who adhere to them in to one single moral community. The Nepali word for religion is dharma, which also means duty, ethics, morality, rule, merit and pious acts. Therefore, when Nepalese discuss religion they understand it with a broader meaning than is usually applied in the West (Bista, 1991). Many native and foreign scholars believe that it is signs and symbols rather than concepts, ideas and fundamentals (Sharma, 1989; Sharma, 2002; Gellner, 2001). Religion in Nepal is principally thought in terms of ritual practices. Ritual practices are different from one locality to others and from one group to others within and among the Hindu Nepalese. The lack of one single uniform religious code, unlike in Islam and Catholicism, is largely because of the legacy of join up of traditionally non-Hindu groups into Hindu fold but retaining their own cultural identity and traditional practices. Many Gurung are having a faith in Hindu creed but follow own cultural identity and traditional practices based on Pye-Tan LhuTan. Gurungs primarily practice ancient Bon religion (pre-Buddhist religion of Tibet), which is Shamanistic and animistic in nature but later came to adopt Tibetan Buddhism. In the current study only 3.3 percent respondents claimed that they believe in Bon. Very modest number of respondents knows about Bon religion despite close involvements with Bon rituals. They are also strongly influenced by Hinduism, and they also observe major Hindu festivals, such as Dashain. In the current study, 35 percent respondents deem Hindu as their religions, 40 percent respondents believe in Buddhism, 21.7 percent respondents believe in both of Hindu/ Buddhist which confirm the influence of Sanskritization and Hinduization process in the urban context.

\section{Table 3: Religion of the Respondents}

Hindu

\section{Religion}

Buddhism

Hindu/Buddhism

Bon

\section{Total}

Frequency

24
Perrcent

40.0

21.7

3.3

100.0

Source: Field Survey, 2014 


\section{d. Reasons for Migration to Pokhara}

39.7 percent respondents migrated to Pokhara to get better education. It shows the changing trend of Lahure culture giving priority to the value of education rather than the military career. 15.9 percent respondents migrated for employment, 36.5 percents for better facilities. Some respondents responded multiple answers regarding the reasons for migration e.g. for education and for better facilities. Rural life is tough and as agriculture alone is not able to prop up a growing rural population of Gurung, internal rural-urban migration is adding to the pressure on already inadequate urban utilities, infrastructure and services in Pokhara. Moreover, migration is also changing the lifestyle of the Gurung people.

\section{Table 4: Reasons for Migration}

Reasons for Migration

\section{Responses \\ Number percent}

For education

For employment

For better facilities

Others

Total (Multiple responses)

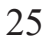

10

23

5

63
$39.7 \%$

$15.9 \%$

$36.5 \%$

$7.9 \%$

100
Percent of Cases
$43.1 \%$

$17.2 \%$

$39.7 \%$

$8.6 \%$

108.6

Source: Field Survey, 2014

\section{Changing Aspects of Gurung Death Rite of Passage}

Cultural influence from Tibetan refugees has facilitated Gurungs adopt the Tibetan Buddhist culture to a profound extent. Pre-Buddhist Tibetan religion (Bön) which is also a major traditional religion of Gurung with heavy influence of Shamanistic cult is on the verge of disappearance in Pokhara. Bonism includes non-Buddhist belief in local deities and in an afterlife in the land of ancestors. Other customary Gurung beliefs comprise spirit possession, supernatural forest creatures, and spirits of humans that died ferociously. Gurung villages usually have their own local deities but the situation changed 
after the migration to Pokhara city.

\subsection{Kind of Culture in Village at the Time of Migration}

The migration of Gurung people to Pokhara is not an abrupt process. Their trend of migration has been slow and steady throughout the years. The Gurung people of Rupakot VDC migrated to Pokhara in the last fifty five years for education, employment and some to get better facilities. 70 percent respondents feel that vital alterations have occurred in their culture after the migration. In the past at their village, buffaloes, goats were sacrificed for meat in food during Pae (Arghun). Villagers help manage things, collecting firewood, making tapari (Plate of leaves). There were problems to carry required stuffs as they did not had the facilities of transportation but there was more co-operation among villagers. At that time people used to gather in Pae (Arghun) to do it more meaningful and to pursue their culture naively but now it seems a bit commercial after their migration to Pokhara.

Table 5: Kind of Culture in the Village at the time of Migration Kind of Culture Frequency Percent

Similar to now

Different than now

Total

No response

Total
7

42

49

11

60
11.7

70.0

81.7

18.3

100.0

Source: Field Survey, 2014

The pre-migration Arghun was conducted in the village with all locally available resources and people's active participation. In the village, they were poor but happy and contented. 
Table 6: Differences that have occurred in Culture after Migration

Similar

\section{Frequency Percent}

8

Different

No response

Total

Source: Field Survey, 2014

75 percent respondents accept that there have been differences in cultures before and now. The differences have been that migration to Pokhara has resulted in a breakup of their social organization as well as in the individual's temporary or permanent segregation from her/ his traditional social (family/lineage/clan/tribe) network. This social and geographical separation is preventing them from celebrating rituals requiring the participation of their village network, or which are intimately linked to ancestral geography, requiring their physical presence in their places of origin. This is true of certain life-cycle ceremonies as death rite and of the cult of ancestors and of the lineage's tutelary deities. It is therefore not surprising that associations as Rupa Samaj has been created to overcome the difficulties in performing various rituals, especially as failure to celebrate them could lead to horrid consequences.

\subsection{Role of Death Rituals in Gurung Community}

The theory of Structural-functionalism is a framework for building theory that sees society as a complex system whose parts namely norms, customs, traditions, and institutions work together to support solidarity and stability (Parsons, 1975). This approach looks at society through a macro-level orientation, which is an extensive focus on the social structures that shape society as a whole, and believes that society has evolved like organisms. This approach looks at both social structure and social functions. It emphasizes the effort to impute, as meticulously as possible, to each feature, custom, 
or practice, its effect on the functioning of a supposedly stable, cohesive system. Pedestal on theoretical perspective of StructuralFunctionalist, Nepali (1965) describes the inter-ethnic, intra-ethnic and inter-caste and intra-caste group relation and interdependence between Newars and how the unity of Newars has been maintained by different rituals. Death rituals too have impinged on Gurung society in different ways. Like much of human behavior, death ritual of Gurung is an expression of a cultural blueprint of values, attitudes, and ideals passed down by parents, and their parents, which individual inherits as a member of society. It leads to notions of souls, gods, witches, spirits and afterworlds. It promises access to their belief and value systems, to their conceptions of the social and moral worlds. It informs that death ritual has consequences for the individual and Gurung culture and society. The Gurung death ritual is embedded in a complex of ideas, sentiments, and values which assume the interrelationship of the body, soul, bereaved, culture and society.

\section{Table 7: Role of Death Rituals in Gurung Community}

\section{The way of Influence}

Gatherings of relatives

Traditional value

Departed soul tortures family members if the ritual is not done properly

Total wastage of money

No response

\section{Total}

Source: Field Survey, 2014
Frequency

17

4

25

2

12

60
Percent

28.3

6.7

41.7

3.3

20.0

100.0

41.7 percent respondents asserted that there is an important role of death ritual. The departed soul tortures family members if the ritual is not performed. Death ritual helps in gathering relatives at one place. Traditional values, customs, traditions, and institutions are strengthened through death rituals that work together to support 
solidarity and stability of Gurung community. Gurung conceive a reciprocal relationship between the living and dead. Both depend upon each other, the living for protection and generosity, and the dead for periodic offerings, respect, and commemoration. Mutual care and concern are the indispensable ingredients in a proper relationship.

\subsection{Changes in Death Rituals in the Last Few Years}

Cultures have been influenced by globalization because of manmade technologies, availability of modern amenities and the migration of people from one place to another. Gurung society has also seen changes in their death rituals during the years after their migration to Pokhara.

\section{Table 8: Changes in Death Rituals in the Last Few Years}

\section{Frequency Percent}

$\begin{array}{llc}\text { Yes } & 35 & 58.3 \\ \text { No } & 25 & 41.7 \\ \text { Total } & \mathbf{6 0} & \mathbf{1 0 0 . 0} \\ \text { Source: Field } & \text { Survey, 2014 } & \end{array}$

58.3 percent respondents accept that different changes are occurring in death rituals. But on the other hand 41.7 percent respondents feel that it has not changed. Likewise, changes in death rituals are leading to ostentatious and expensive behaviors. The trend is also on rise to organize one night long Pae (Arghun) in place of traditional three nights Pae (Arghun).

\section{Table 9: Changes Perceived}

\section{Changes Perceive}

It has become more ostentatious (showy)

It has become more expensive

\section{Frequency Percent}

16

26.7

12

20.0 
Increase in accepting one night

Pae (Arghun)

No response

\section{Total}

Source: Field Survey, 2014
4

6.7

28

46.7

60

Before the period of migration and urbanization, there existed indigenous, autonomous, distinct and well defined, tough and culturally sustaining connections between geographical place and cultural experiences of Gurung which constituted one to one community cultural identity, which was often considered as something Gurung people were an undisturbed existential control, an inheritance, a benefit of traditional long dwelling along with the continuity of past. However after the migration in an urban setting of Pokhara, it is perceived that Gurung cultural identity is getting fragile that needed protection and preservation that could lose from the mordant force of urbanization and modernization. Urban culture embedded with modernization has flounced Gurung community's diverse cultures, destroying stable localities, relocating Gurung people, bringing market-driven, branded homogenized cultural experiences. Urbanization and modernization involved as a general process of loss of Gurung traditional cultural norms, raise of pretentious behavior and high expenditures on different rituals.

\subsection{Performing One Night (Ek Rate) Pae instead of Three Nights (Teen Rate) Pae}

Gurung priests are called Ghepren, Pachyu, Paindi and Lama. Ghepren and Pachyu do not conduct one night (Ek Rate Pae/Arghun). Bon Lamas also perform death ceremony similar to Ghepren and Pachyu. However, after the settlement of Tibetan refugees in Pokhara since 1960's, Gurungs are influenced more by Tibetan Buddhism. While conducting different rituals, Gurungs of Pokhara has started to take the help of Tibetan Lamas. The traditional Gurung Bon Lamas are gradually fading. Ek Rate Pae (Arghun) conducted by Tibetan Lama is a paradigm of changing pattern of Gurung death ritual in Pokhara. Tibetan Lamas perform all rites in Ek Tate Pae which is 
usually done in Teen Rate Pae (Arghun) performed by traditional Gurung Bon Lamas. Ek Rate Pae is of short period lasting for single day hence it is easy, cost-effective and saves time.

\section{Table 10: Reasons for Performing Ek Rate Pae (Arghun)}

Reasons

To save time

To minimize expenditure

It's a traditional culture

To change traditional custom

$\mathrm{N} \quad$ percent

18

39

8

10

75
Percent of

Cases

31.6

68.4

17.5

131.6

Source: Field Survey, 2014

Huge number of respondents believed Ek Rate Pae (Arghun) is performed for minimizing expenditure. Definitely one day ritual makes more minimization in expenditure and saves time. The table 5.6 depicts more than 60 responses because of the multiple answers of 15 respondents. Different internal changes have occurred in death ritual. The feeling of community building is a positive outcome. It has helped unite the migrated people at a place for different functions. Furthermore, the space, utensils, work division and communication has become easy and accessible. When doing the Pae (Arghun), there are many important emotional, scientific events in death ritual which is explained in Pye-Tan-Lhu-Tan. Death ritual as Ek Rate Pae is the medium for making chain of relatives for Gurungs. It has been the best medium of integration, interaction and stability in Gurung society.

\subsection{Modifications Required in Death Rituals}

There is the amplification of pecuniary ostentations, adoption of external cultures and other religions effects in Gurung rites hence Gurung people reckon to modify issues as expenditure on Pae 
which should be strongly reduced. 11.7 percent suggest that over expenditure should be strongly reduced, 17 percent respondents responded that priests should be more qualified. 10 percent respondents deem that animals sacrifice during death rituals should be stopped up. Additionally, 36\% respondents suggested that time limitation should be fixed in death rites, stop provision of alcohol; rate should be fixed for Syaisyai, discouragement for money making activities during death rituals and no more donation.

\section{Table 11: Modifications Required}

\section{Aspects to be Modified}

Over expenditure should be strongly 7

Frequency Percent

reduced

Priests should be more qualified

Rituals should be custom oriented

Sacrificing animals should be stopped 6

It should be shortened to make more 3 convenient

Time limitations in death rituals, stop 36 alcohol; fixing rate for Syaisyai, discouraging money making activities

\section{Total}

60

Source: Field Survey, 2014

\section{6 Syaisyai as an Institution and Economy in Syaisyai}

In his book "The Gift" (1925) Mauss proposed that the social whole could be conceived as a system of exchange. He argued that economy is not only maximization of profit but a system based on relationship and that gifts are never "free" rather gifts give rise to reciprocal exchange. In Gurung community Syaisyai is a special/tribute and unique ritual based on gift. Syaisyai is kind of compliment rendered on all special occasions-both happy and gloomy. In death ritual people go to do Syaisyai for condolence and 
for maintaining good relation between families and in the process they donate money to the bereaved family. Special power resides in the object given (money or anything else) that causes its recipient to pay it back. Syaisyai as a gift is a "total presentation", imbued with "spiritual mechanisms", engaging the honor of both giver and receiver. Such dealings go beyond the divisions between the spiritual and the material in a way that according to Mauss is almost "magical". In Syaisyai giver does not merely give money but also is a part of it, for the donation is indissolubly tied to the giver. This bond between giver and gift, the act of giving creates a social bond in Gurung community with an obligation to reciprocate on the part of the recipient. Not to reciprocate means to lose honor and status and the spiritual implications can be even worse. Provided that there is a high significance of Syaisyai, it is of core essence in Gurung community. However, it is deduced from this study that Syaisyai is becoming showy and flamboyant. Rich people donate huge amount of money but poor give less hence a sharp divergence is created, increasing deformities in society. It is transforming into an expensive exchange business, a reciprocal relationship. 13.3 percent respondents have accepted that it is precise to do Syaisyai with rich people donating more money and poor giving less. However 86.7 percent respondents have not accepted this; they don't like to do Syaisyai as an exchange with rich people donating more money and poor giving less. They prefer equality and very limited amount to be fixed while giving money as Syaisyai, but rituals should not be buckled.

\section{Table 11: Making Syaisyai more Economical}

\section{Frequency Percent}

Rich people should give

8

more money

There should be equality

86.7
Total
Source: Field Survey, 2014
60
100.0

Open register to keep record is the feature of system of exchange in Syaisyai. Rich people go to do Syaisyai by donating more money 
than mentioned in record register. For example, if there is record of Syaisyai Rs. 2000, she/her can donate more than this, may be Rs. 2500. This trend has brought exchange tradition at the crossroad of becoming a commercial act, people getting selfish, money-centered and discriminating to human relations. It is bringing bigotry in Gurung society, categorization of people as superior and inferior, rich and poor. Despite this, Syaisyai as a custom of exchange exist as a symbolic value of sharing sorrow and joy. Neither it was compelled nor does it maintain compensation. It is voluntary consequently it should not be a burden for poor. It is helping to build up a mutual relationship among Gurungs, between their kin that has supported the solidarity of Gurung kin in the social system and strengthened Gurung community.

\section{Changes in Death Rites: Actors and Factors}

Rituals are traditions and are by and large concerned to replicate historical precedents accurately. Traditionalism varies from formalism in that the ritual may not be formal yet still makes an appeal to historical. A rite of passage is a ritual event that marks a person's transition from one status to another, including birth, coming-of-age, marriage, death as well as initiation into groups not tied to a formal stage of life such as a fraternity. Death Ritual is also a part of rite of passage. Having changes in these is called cultural change. There are many causes or factors of culture to be changed. Gurung people have long traditions of serving the armed forces. Also they were fascinated by foreign jobs since of the high payment. As they exposed to the outside world, they imitate the modern lifestyle. It did not necessarily mean they have no conviction towards their indigenous culture. It is one of the traditional societies having lot of traditional characteristics but modernization and urbanization is obliterating cultural identities and Gurung indigenous culture is continuously changed.

\subsection{Roles of Modernization and Urbanization in Pioneering Changes in Death Rites}

Modernization is associated with westernization because it initiated 
in the West. In 19th and 20th centuries the world was Euro-centric as all the foremost world powers were West European nations that had colonized the countries of Africa and Asia. So when the changes concerning to modernization took place, they were attributed to the West Europe and the course of action was intimately associated with westernization as a process whereby societies come under or espouse western culture in such matters as religion, philosophy and values, lifestyle, industry, technology, politics, economy, food habits, language etc. Likewise, as process urbanization is the substantial growth of urban area as an upshot of migration and suburban concentrations into cities. It is a specific condition at a set time with various long term consequences in the culture and lifestyle. The migration of Gurung people from Rupakot and settlement in Pokhara city has led to different types of changes in their life. The people of Rupakot carry out Pae (Arghun) in urban Pokhara because their kiths are in urban (Pokhara). The means of transportation and communication have made easier for lodging, gathering, informing etc. There is a rule and custom to comply with and invite relatives, priests etc. Nowadays, invitees are contacted by phone. Some customs has been modified and going to be lost. The Syaisyai culture is also continuing in the form of exchange keeping records in register. There is slight modification on some customs for reduction of high expenditure, for example, in the case of three days Pae only on last, they provide meat and only three ritual sheep are used for grazing. There are changes in the uses of alcohol. Nowadays wine, bear, whiskey etc. are consumed in place of domestic wine ( $p a$ ) which is the original culture and essential for Gurungs for every ritual. Excessive costs intertwined with excessive use of expensive wines makes it difficult for poor people to conduct Pae because of high economic burden. The whole context has been affected by ostentations and expensiveness of Lahure culture in an urban context spending huge amounts in different functions. Now, dead body is covered by wreath of money instead of flower garland.

Gurung youth go abroad for employment in British Army, Indian Army and in Gulf countries, Malaysia, Japan, Korea, Hongkong etc for labour. Hence, Gurung people have become more impetuous while making a use of money, buying a plot of land and constructing 
a modern big house in city center. Even their culture and rituals are also affected by modernization and urbanization. The use of technology (mobiles, vehicles, television etc.) has made easy for gathering, conveying information, transportation of materials and resources etc.

Table 12: Influence of Modernization and Urbanization

\section{Responses}

Yes

No

Total
Source: Field Survey, 2014

\section{Percent}

96.7

3.3

100.0

96.7 percent respondents believe that modernization and urbanization has deeply influenced death rite and 3.3 percent respondents believe that there is no influence. Modernization and urbanization align to facilities for conducting rituals, rites and functions. Gurung death ritual has been influenced by education, economic life, population growth, other societies, migration etc. Gurung death rite has been modified by predominant urban culture denoting an evolutionary transition from a pre-modern or traditional to a modern urban society. Traditional religious beliefs and cultural traits have become less important as modernization took place. Death ritual has become cost intensive, more showy (decorative, competitive), adaptation of modern means (vehicle, sound system, alcohol).

\section{Table 13: Major Influences}

Major Influences

Alignment to facilities

Ostentatious gaudy nature

has increased

Expenditure has increased

No response

Total

Source: Field Survey, 2014

\section{Frequency Percent}

51

4 
85 percent respondents deem main influences in alignment to facilities by modernization and urbanization. Absurd behaviors, spending more, displaying glitzy nature by wearing heavy gold ornaments, and giving huge money in Syaisyai are the part of their gaudy culture. 6.7 Percent respondents believe that ostentatious behavior is obliterating their indigenous culture. Death rite of Gurung is emotional and effective in life but basic rudiments of their fundamental culture has being infected by modernization and urbanization effect. Wallance (1956) has squabble that, when society faces a series of problems people become nostalgic for an idealized past period. There emerges the concept of cultural revitalization which can be defined as "A deliberate, organized, conscious effort by members of a society to construct a more satisfying culture". According to him, it is a special kind of cultural change. Those involved in the process of revitalization must perceive their culture or some major areas of it, as a system (whether accurately or not). Further, they must have felt that this cultural system is unsatisfactory, and they must innovate not merely discrete items, but a new cultural system, specifying new relationships as well as in some case new traits. The Gurung people are lately sensitizing that their traditional rituals have been duped by vicious assault of modernization and urbanization trend hence it is indispensable to specify new relationships as well as in some case new trait.

There are some positive impacts of modernization and urbanization. For example they have made life easy by making accessible facilities/ stuffs for performing various rituals. In the past time, there was less expenses due to excessive use of labor-intensive power to carry loads, to do various works etc. Now a day, if Gurung people are able to spent money, every thing is available immediately and easily in the urban milieu. It is the constructive side of modernization and urbanization, however it is arduous. Likewise, in a modern urban context more and more people are proving self-centered and selfish in the case of economic activities, where affluent people are overgenerous. There are also various instances of Gurung people taking the service of Lama in performing Pae (Arghun) in Gumba (Monastery) by ignoring relatives and not inviting them. In broad-spectrum, urbanization impact on Gurung death ritual can be closely linked 
to modernization and the sociological process of rationalization, a speedy and historic transformation of Gurung social roots whereby predominantly rural traditional Gurung culture is being rapidly modified by principally urban culture of Pokhara.

\subsection{Aspects of Changes in Gurung Death Rites owing to External Exodus}

The traditional religion of Gurung is Bonism pedestal on Shamanism. Gurung people have been performing many cultural rituals based on Bonism. They are nature and ancestor worshippers. Gurungs conventional priests Pachyu, Ghepren and Bon Lama perform rituals as naturalist. However, after the settlement of exodus Tibetan refugees in Pokhara, the influence of Tibetan Mahayani Lamaism culture has increased in Gurung death Rituals. Many Gurung people are attracted to Tibetan Lamaism by parting off their traditional culture and priests. The main reasons may be due to close cultural affinities between Gurung and Tibetan cultures, less availability of traditional Gurung priests, more economical rituals etc. No animal and birds fowl is sacrificed in death ritual under the Tibetan Mahayani tradition hence it is comparatively cheap to manage the rituals without animals and fowl.

Wallerstein (1974) has noted that indigenous peoples have more enemies than either capitalism or neo liberal modernization and westernization. The Tibetan influence on indigenous Gurung culture has resulted in the disappearance of many of the traditional norms of indigenous Gurung culture. According to Bhattachan (2008), the influences on the indigenous cultures have been seen before the territorial unification of the country Nepal. The country never faced the colonization and discrimination from outsiders like in the cases of the neighboring countries but indigenous societies were victimized by the state in the name of "National Unification". Thus, in the name of "Hinduization" or "Sanskritization" indigenous people were divided into different castes and thus introduced to new religions and languages. In the context of Gurung, although there is an influence of Hindu religion while celebrating Hindu festivals like Dashain, the influence of Hindu culture in death rite 
is not perceived so much. However, there is the tendency that many Gurung people claim 'Hindu' as their religion. It can be said that it is the influence of close contact with their Hindu neighbors in Pokhara. Few Gurungs are acquainted to their traditional religion Bon. Majority assume Buddhism as their religion. There are heavy manipulations of Tibetan Lamaism. There are many Gurung people who hire both traditional Ghepren/Pachyu and Tibetan Lama in death rite. It is a kind of assimilation of traditional Gurung Bonism with Tibetan Mahayani Lamaism. There are various aspects of this changing process that has been depicted in table.

\section{Table 14: Aspects of Changing Process Aspects of Changing}

Process

\section{Frequency}

Economic

Religious

Other Reasons

Total

No response

Total
20
16
6
2
44
16

60

\section{Percent}

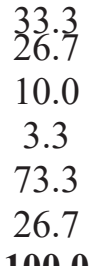

100.0

Source: Field Survey, 2014

Majority (33\%) regarded economic factor as a major reason behind the growing influence of Tibetan Lamaism in Gurung death ritual. Only 10 percent respondents accepted influences of other religion (Hindu) in Gurung death rite. 26 percent respondents hold responsible social factors (family, education, locality, type of neighbors, life partner and children, political system) as the major forces. The facts and experiences influencing individual personality, attitudes and lifestyle, consumer behaviors stood vital. Due to the accessibility of modern information technology, different ideas, innovation are spreading in the urban context. Modernization and urbanization can't be termed something harsh to Gurung traditions. It is better for them to find the better means between or by combining their traditions and modern factors so that they can be modified then in the right way on the behalf of their community amid the sharp assail of migration, urbanization and modernization. The Gurung 
people and their systems are plain and flexible hence they can easily fuse into their own custom and society.

\section{Conclusion}

All through the human history, indigenous people have developed ceremonies and rituals to help make sense or celebrate a change in position, circumstance or relationship. Ritual often accompanies births, marriages and death. The transition from one life stage to the next is gratifying. Over time some rituals become diluted, tarnished or less accepted by the youth for whom they are intended. In majority of cultures, the greatest effort is given to the death rite of passageand yet paradoxically it is the one that is now most often distorted or lost. For the Gurungs, death is of key symbolic significance that involves the dissolution of elements that make up the body, so that the earth element returns to earth, air to air, fire to fire, and water to water. This process leaves the souls, which must be sent through the performance of the Pae or Arghun to the land of the ancestors. There life continues much as it does in the present world, and from there the spirit can acquire other rebirths. If the soul does not get salvation it may give pain to kiths and kin. Hence, it is indispensable to perform Pae to give salvation to departed soul. Hence, Gurungs conceive a reciprocal relationship between the living and dead-- both depending upon each other, the living for protection and generosity, and the dead for periodic offerings, respect, and commemoration.

Under the brisk process of migration to urban areas, the trend of organizing Pae is changing in Pokhara which is result of various actors and factors. Based on Durkheim's (1893) notion of Mechanical Solidarity and Organic Solidarity of ideal society it has been deduced in this study that Gurung community is changing from Mechanical to Organic Solidarity in which the Mechanical Unity of their traditional culture is transforming to loosely united Organic Solidarity of body. Death rites of Gurungs have been influenced by many rudiments as migration, urbanization and modernization.

In Pye-Tan Lhu Tan (Gurung religious text), there are many methods and creations of culture. And most important implication 
of death rituals in Gurung community is solidarity based on the notion of Functionalism. Harmony, sympathy, interdependency and interrelation among Gurung people member of society are the results that has kept intact Gurung rituals despite their migration to urban centers, spiky assault of modernization and urbanization. The influences of urbanization and modernization have brought some changes and modifications in death rituals too making it more expensive, ostentatious and competitive. Different forms of competitions has erupted among people and hidden conflict (manifest) has been felt between priests and people about process, between old and new generation about knowledge of ritual, culture and the role of Pye-Tan Lhu-Tan. It has become economically, religiously, and culturally burden for many despite its role in creating harmony and solidarity in Gurung Community. Urbanization impact on Gurung death ritual can be intimately linked to modernization and the sociological process of rationalization, a prompt and momentous transformation of Gurung social roots whereby chiefly rural Gurung culture is being swiftly modified and replaced by urban culture. The changes and assimilations occurring in death rituals have also led to the rise of consciousness among Gurungs ---that their traditional religion is not Buddhism or Hindu but Bon and that they are nature and ancestors worshippers. A consciousness has developed to rummage around and preserve their original religion.

\section{References}

Bhattachan, K. B. (2008). Minorities and indigenous peoples of Nepal. Kathmandu: National Coalition Against Racial Discrimination (NCARD).

Bista, D. B. (1991). Fatalism and development: Nepal's struggle for modernization. Calcutta: Orient Longman.

CBS (2011). National population and housing census (NPHC). Kathmandu, Nepal.

Durkheim, E. (1893). The division of labour in society. New York: Free Press.

Gellner, D. N. (2001). The anthropology of Buddhism and Hinduism.

New Delhi: Oxford University Press.

Gurung, J. (1977). Gurung Jaati Tatha Sankriti. Pokhara: Pokhara 
Centre Press.

Mauss, M. (2002). The Gift. Great Britain: Routledge.

Messerschmidt, D. A. (1976). The Gurungs of Nepal: Conflict and change in a village society. Warminster; Aris \&Phillips Ltd. Nepali, G. S. (1965). The Newars. Bombay: United Asia Publication. Parsons, Talcott, (1975). The Present Status of "StructuralFunctional" Theory in Sociology. In Talcott Parsons, Social Systems and The Evolution of Action Theory New York: The Free Press.

Pignede, B. (1966). The Gurungs: A Himalayan population of Nepal. Kathmandu: Ratna Pustak Bhandar.

Sharma, P. R. (1989). Nepali Society and Culture: Reflections on Some Historical Currents. In Kamal P. Malla (ed.) Nepal: Perspectives on Continuity and Change. Kathmandu: Centre for Nepal and Asian Studies, pp. 139-168.

Sharma, S. (2002). The Hindu State and the State of Hinduism. In Kanak Mani Dixit and Shastri Ramachandaran (eds.) State of Nepal. Kathmandu: Himal Books.

Tylor, E. B. (1865). Researches into the early history of mankind and development of civilization. London, Free Press.

Van Gennep, Arnold. (2010). The rites of passage. Routledge Chapman \& Hal.

Wallance, A. F. C. (1956). Revitalization Movements. American Anthropologist, new Series, vol. 58, no 2.

Wallerstein, Immanuel (1974). The modern world-system: Capitalist agriculture and the origins of European world-economy in the sixteenth century. New York: Academic Press. 